\title{
"Cavity spilling" perforation during recanalisation of the right coronary artery - reocclusion of the recanalised artery as a method of emergency treatment
}

Perforacja typu cavity spilling w trakcie rekanalizacji prawej tętnicy wieńcowej ponowne zamknięcie rekanalizowanej tętnicy jako metoda postępowania ratunkowego

\author{
Marek Kurianowicz ${ }^{1}$, Tomasz Zapolski ${ }^{1,2}$, Robert Wróbel ${ }^{1}$, Jakub Drozd ${ }^{1,3}$ \\ 1Department of Cardiology, The Voivodal Specialistic Hospital, Biala Podlaska, Poland \\ ${ }^{2}$ Chair and Department of Cardiology, Medical University, Lublin, Poland \\ ${ }^{3}$ Department of Interventional Roentgenodiagnostics-Hemodynamics, Hospital of the Ministry of Interior and Administration, Lublin, Poland
}

Post Kardiol Interw 2012; 8, 1 (27): 51-56

DOI: $10.5114 /$ pwki.2012.27926

\begin{abstract}
Coronary artery perforation is an uncommon but potentially life-threatening complication of percutaneous coronary interventions. We report a case of a 78-year-old patient with "cavity spilling" right coronary artery perforation leading to formation of a fistula with contrast spilling directly to the right ventricle which occurred during recanalisation of the chronically occluded coronary artery. This rare complication was treated with a polytetrafluoroethylene-covered stent graft implanted into the right ventricular artery at the site of the right ventricular branch, followed by reocclusion of the right coronary artery and complete patient recovery. A control coronary angiography after 6 months has been scheduled.
\end{abstract}

Key words: perforation, coronary artery fistula, cavity spilling, stent graft

\section{Streszczenie}

Perforacja tętnicy wieńcowej jest rzadkim powikłaniem przezskórnych interwencji wieńcowych, stanowiącym potencjalne zagrożenie życia. Przedstawiono przypadek perforacji typu cavity spilling prawej tętnicy wieńcowej w czasie rekanalizacji długotrwale zamkniętej tętnicy u 78-letniej chorej z wytworzeniem przetoki do prawej komory serca. To niezwykle rzadkie powikłanie opanowano poprzez implantację do początkowego odcinka prawej tętnicy wieńcowej i jej gałęzi prawokomorowej stentgraftu pokrytego politetrafluoroetylenem, co spowodowało ponowne zamknięcie rekanalizowanej tętnicy, ale pozwoliło na pełną stabilizację stanu chorej. Zaplanowano wykonanie kontrolnej koronarografii za 6 miesięcy.

Słowa kluczowe: perforacja, przetoka wieńcowa, cavity spilling, stentgraft

\section{Introduction}

Coronary artery perforation is a rare but very severe complication of percutaneous coronary interventions (PCI). Its frequency ranges from $0.1 \%$ to $3.0 \%$ [1-4]. Clinical factors predisposing to perforation include older age and female sex [1]. The risk of perforation is mainly related to the presence of a three-vessel disease and B2 or C type atherosclerotic lesions, especially those caused by chronic occlusions and accompanied by calcifications. The risk of perforation is also mediated by the type of devices used to open the artery such as a rotablator or an excimer laser [2, 5]. Perforations are more likely to occur with the use of hydrophilic guidewires, especially those that are stiff and have a high tensile strength [6]. Other causes include the use of too large balloons or stents unadjusted to the vessel size.

We present a case of a perforation during recanalisation of the chronic total occlusion (СТO) of the coronary artery. The reason for perforation was rather typical, but the management, although influenced by the situation, was unconventional and, what is most important, effective.

Corresponding author/Adres do korespondencji:

Tomasz Zapolski MD, PhD, Chair and Department of Cardiology, Medical University, 8 Jaczewskiego St, 20-950 Lublin, Poland, fax: +48 81724 41 51, e-mail: zapolia@wp.pl

Praca wpłynęła: 29.11.2011, przyjęta do druku: 30.01.2012. 


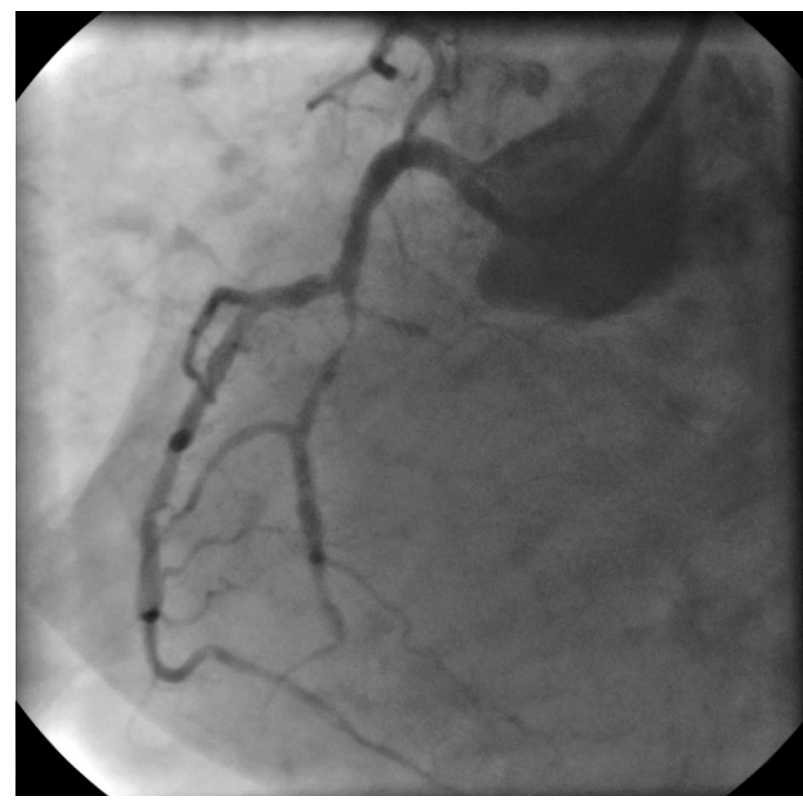

Fig. 1. Right coronary artery (LAO $48^{\circ}, \mathrm{CAU} 6^{\circ}$ view) - visible critical stenosis (right below the ostium of the right ventricular branch) and total occlusion in the middle segment

Ryc. 1. Prawa tętnica wieńcowa (projekcja LAO 48, $C A \cup 6^{\circ}$ ) - widoczne krytyczne zwężenie (tuż po oddaniu gatęzi prawokomorowej), a następnie zamknięcie w środkowym odcinku

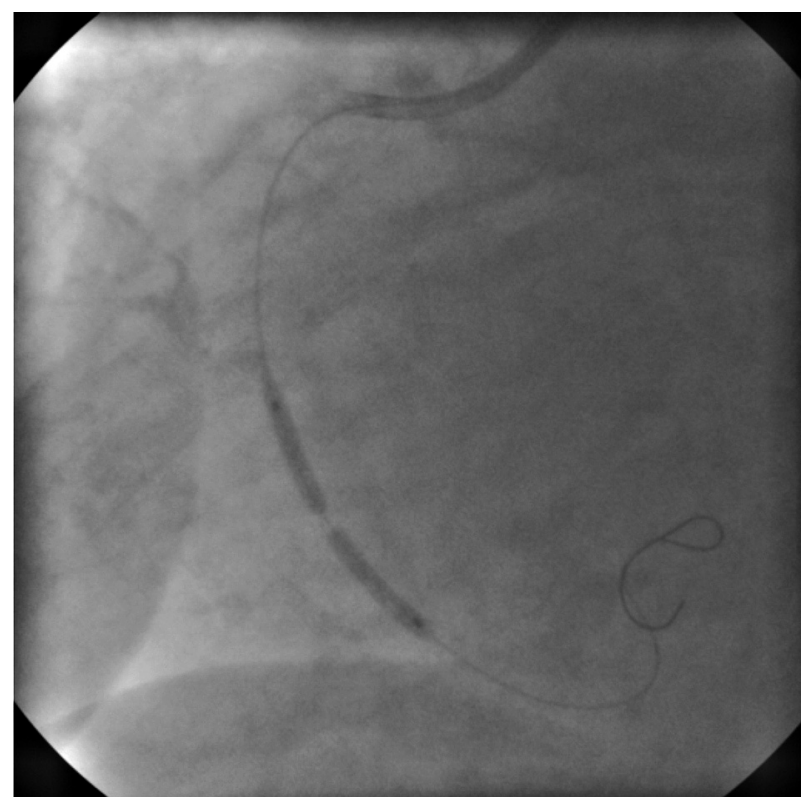

Fig. 2. Right coronary artery (LAO $51^{\circ}$, CAU $1^{\circ}$ view) - balloon inflation, visible balloon modelling on a hard lesion (the site of occlusion)

Ryc. 2. Prawa tętnica wieńcowa (projekcja LAO 51, $\left.C A \cup 1^{\circ}\right)$ - inflacja balonowa, widoczne modelowanie się balonu na twardej zmianie (miejsce okluzji)

\section{Case report}

\section{Clinical data}

A 78-year-old female patient with symptoms of stable angina CCS class II was admitted for an elective recanalisation of the right coronary artery (RCA). The patient had a history of myocardial infarction of the inferior wall (STEMI) in 2011 treated with $\mathrm{PCl}$ of the circumflex artery (CX) with bare metal stent implantation. In June 2011 the patient suffered from a non-ST-segment elevation myocardial infarction (NSTEMI). Coronary angiography performed at that time revealed the presence of the following changes: RCA - critical stenosis in the middle segment and occlusion in the distal segment of the vessel (Figure 1), LM - no changes, LAD - parietal changes, CX - ostial occlusion. Due to the presence of symptoms of myocardial infarction an ad hoc successful CX recanalisation with drug-eluting stent implantation was performed (Endeavor Resolute 3.0/30 and Endeavor 2.75/30 - Medtronic).

The patient medical history included previous implantation of a vascular prosthesis for the treatment of Leriche syndrome, previous radiotherapy for the treatment of cervical cancer, and thyroid goitre in the state of euthyroidism. Pharmacotherapy included clopidogrel $1 \times 75 \mathrm{mg}$, aspirin $75 \mathrm{mg}$, atorvastatin $40 \mathrm{mg}$, metoprolol succinate $1 \times 25 \mathrm{mg}$ and pentoxifylline $2 \times 400 \mathrm{mg}$ (Figure 1 ).

\section{Description of the procedure}

Recanalisation of the RCA was attempted via the left radial access. After cannulation of the RCA ostium with

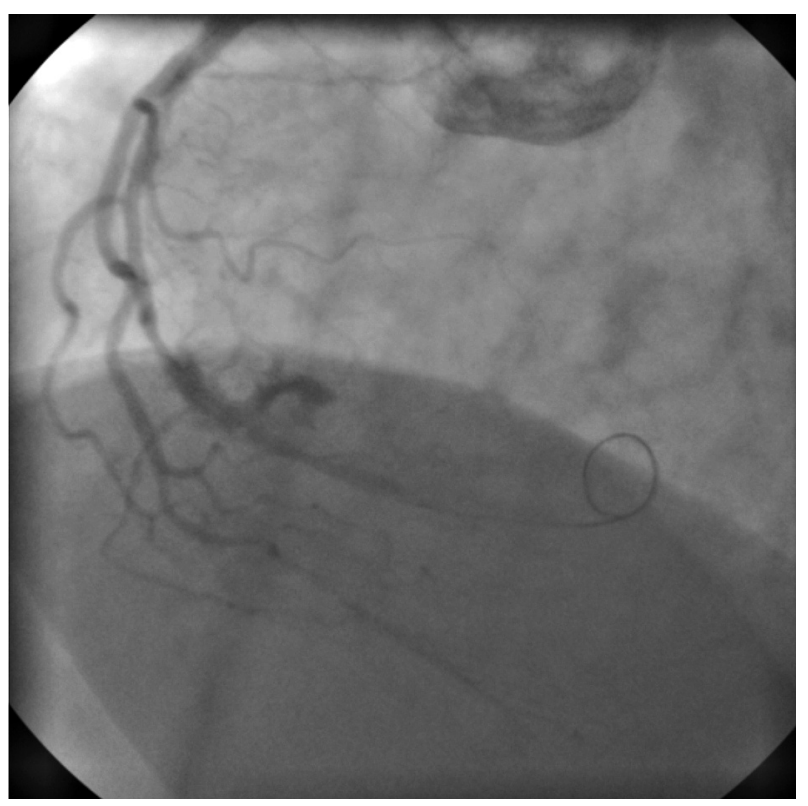

Fig. 3. Right coronary artery (LAO 51으 CAU $1^{\circ}$ view) - a small extravasation of contrast medium into the right ventricular cavity is seen

Ryc. 3. Prawa tętnica wieńcowa (projekcja LAO 51, $\left.C A U 1^{\circ}\right)$ - widoczne niewielkie wynaczynienie zakontrastowanej krwi do jamy prawej komory 


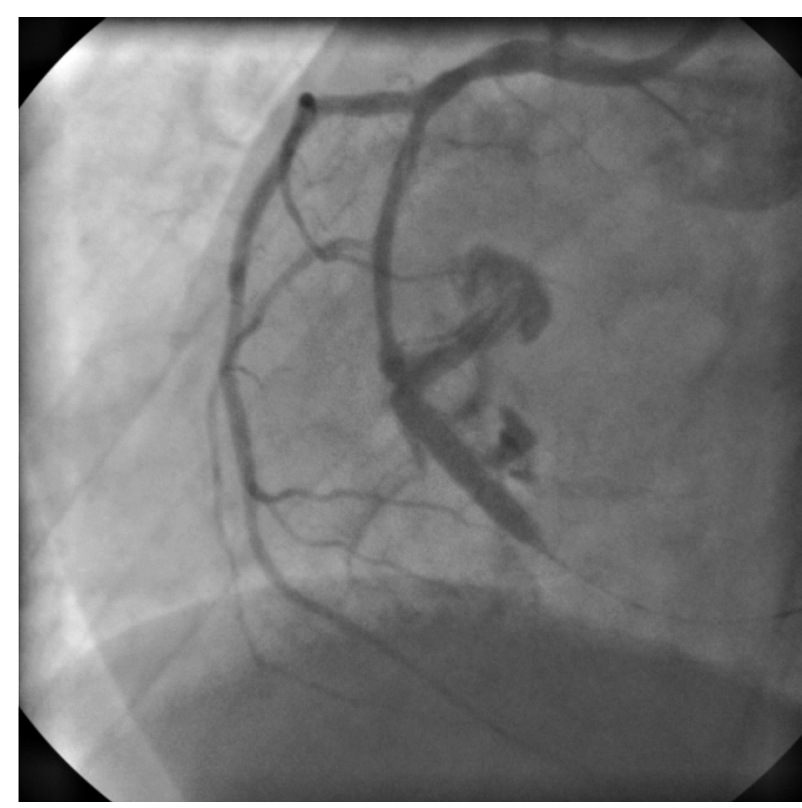

Fig. 4. Right coronary artery (LAO $29^{\circ}, \mathrm{CRA} 11^{\circ}$ view) - an increase of the contrast medium extravasation after drug-eluting stent implantation; clearly visible ostium of perforation located in the site of a former occlusion, now in the proximal part of the stent

Ryc. 4. Prawa tętnica wieńcowa (projekcja LAO 29, CRA $11^{\circ}$ ) - nasilenie wynaczynienia zakontrastowanej krwi po implantacji stentu uwalniającego lek; wyraźnie widoczne wrota perforacji w miejscu początkowej okluzji, obecnie na górnym biegunie stentu

a guiding catheter JR4 $6 \mathrm{~F}$ (Launcher, Medtronic) and administration of $6500 \mathrm{IU}$ of unfractionated heparin the Pilot-50 0.014 guidewire (Abbott) was easily introduced through the occlusion site. This step was followed by predilation with a balloon catheter Mini Trek 2.0/25 (Abbott) to $18 \mathrm{~atm}$, which did not lead to dilation of the lesion. Full dilation of the lesion was obtained using the non-compliant NC Trek 2.5/25 balloon (Abbott) inflated to high pressure (28 atm). Inflations with lower pressures led to balloon modelling on the lesion, which suggested marked "hardness" of the lesion, and were a marker confirming the presence of a long-lasting occlusion (Figure 2). A control contrast injection performed after predilation showed a mild contrast leak (Figure 3). Leakage was stopped with prolonged balloon inflation. A decision was made to implant a drug-eluting stent, Xience V 2.75/23 (Abbott), at $12 \mathrm{~atm}$. Stent implantation led to a marked increase of blood extravasation, suggesting a communication between the RCA and the right ventricle (Figures 4-6). An attempt to stop bleeding with prolonged $(5 \mathrm{~min}$ ) inflation of the stent balloon at the site of the perforation was made. Due to increase of bleeding (Figure 7) it was decided to implant a stent graft. An attempt to introduce it down to the site

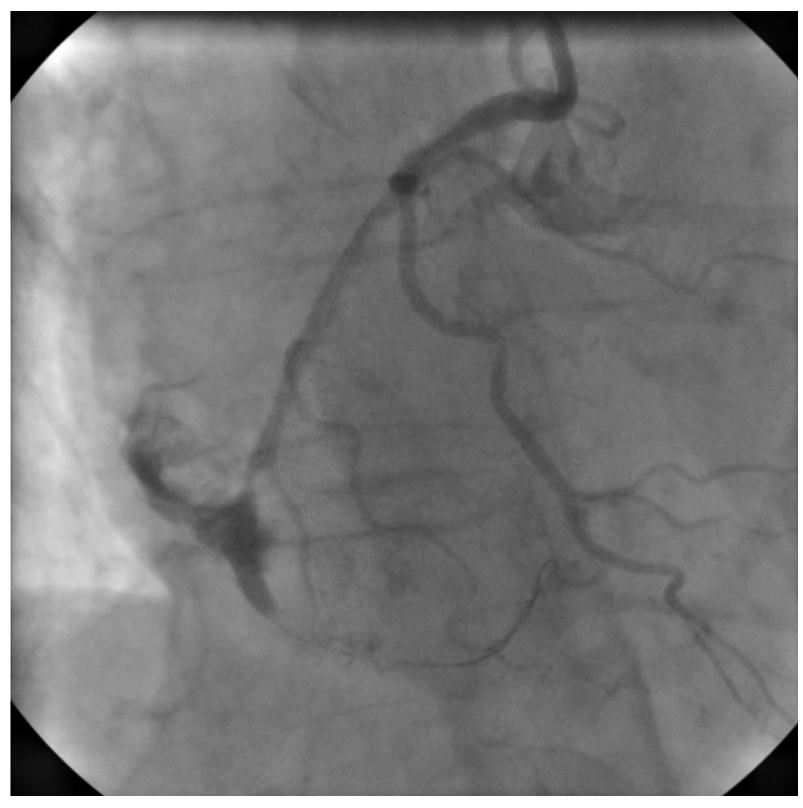

Fig. 5. Right coronary artery (RAO $29^{\circ}, \mathrm{CRA} 3^{\circ}$ view) - an increase of the contrast medium extravasation after drug-eluting stent implantation; clearly visible ostium of perforation located in the site of a former occlusion, now in the proximal part of the stent Ryc. 5. Prawa tętnica wieńcowa (projekcja RAO 29०, CRA $3^{\circ}$ ) - nasilenie wynaczynienia zakontrastowanej krwi po implantacji stentu uwalniajacego lek; wyraźnie widoczne wrota perforacji w miejscu początkowej okluzji, obecnie na górnym biegunie stentu

of the perforation was unsuccessful. Therefore it was decided to reocclude the recanalised artery by stent graft implantation at the site of RCA-right ventricular branch bifurcation. After introduction of an additional guidewire, Whisper MS 0.014 (Abbott), into the right ventricular branch, a direct stent graft implantation was performed (Jostnet GraftMaster 3.0/16, $12 \mathrm{amt}$-Abbott) (Figure 8), leading to complete cessation of blood extravasation into the right ventricle (Figures 9-10). The time of fluoroscopy was $15.8 \mathrm{~min}$; radiation dose was $1.9 \mathrm{~Gy}$ and $210 \mathrm{ml}$ of Imoeron contrast was used (Bracco S.p.A. Patheon Italia S.P.A.).

Despite the described complications the patient remained haemodynamically stable throughout the whole procedure. She did not complain of any pain. Repeated echocardiographic examinations performed after the procedure did not show the presence of pericardial fluid.

\section{Discussion}

The currently used classification of perforations was proposed in 1994 by Ellis et al. [1]. It consists of 3 types: type I - extravascular limited crater of contrast without extravasation; type II - pericardial or myocardial blush with- 


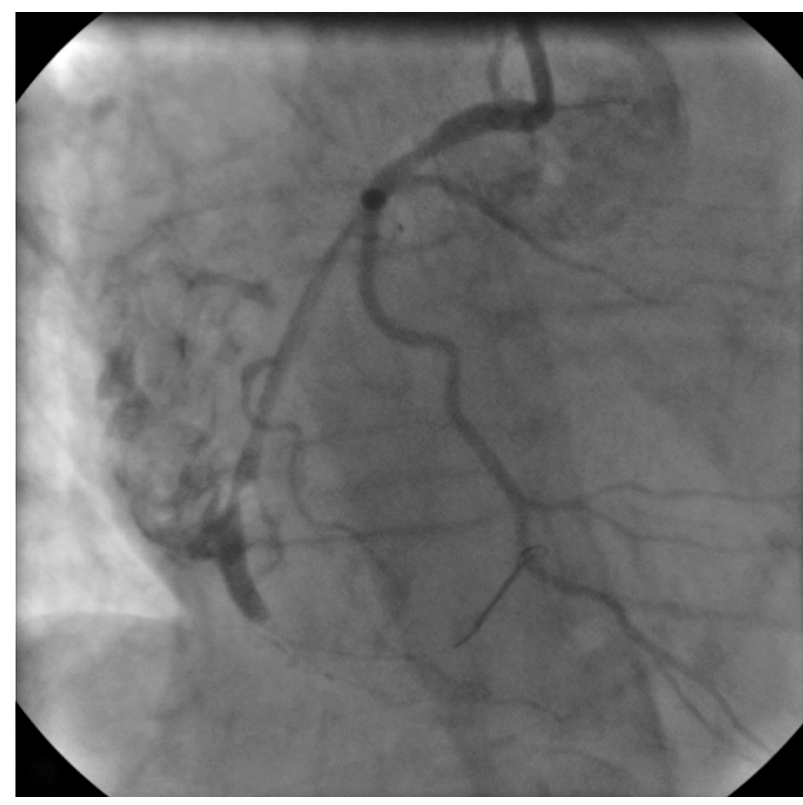

Fig. 6. Right coronary artery (RAO $29^{\circ}$, CRA $3^{\circ}$ view) - an increase of the contrast medium extravasation after drug-eluting stent implantation; contrast spills into the right ventricular cavity

Ryc. 6. Prawa tętnica wieńcowa (projekcja RAO 29, CRA $\left.3^{\circ}\right)$ - nasilenie wynaczynienia zakontrastowanej krwi po implantacji stentu uwalniajacego lek; kontrast rozlewa się w prawej jamie komory

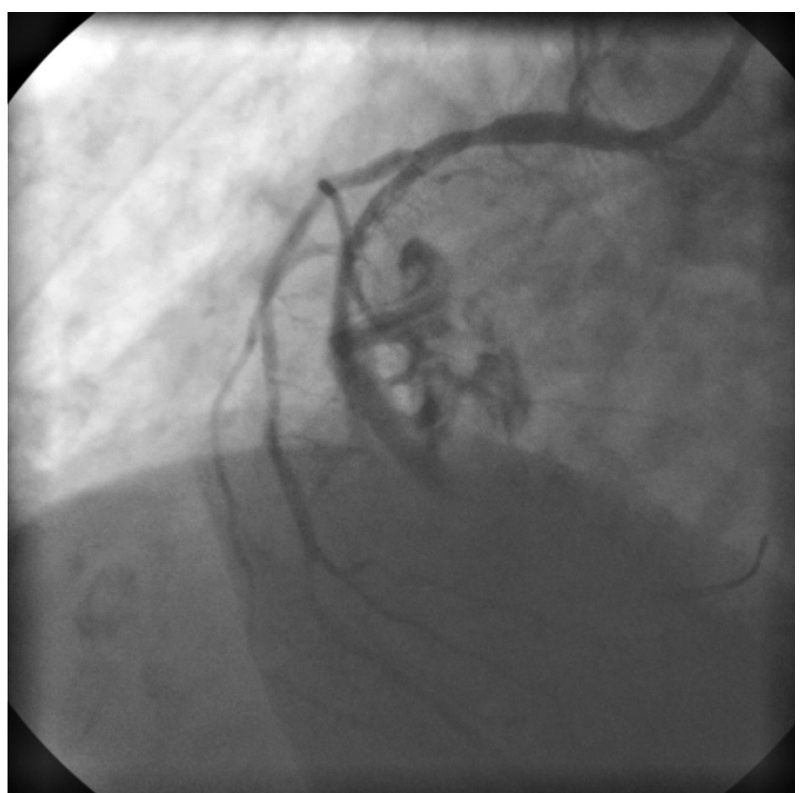

Fig. 7. Right coronary artery (LAO $17^{\circ}$, CRA $19^{\circ}$ view) - a massive contrast medium extravasation after prolonged balloon inflation; two clearly visible sites of perforation localized in the proximal and middle part of the stent

Ryc. 7. Prawa tętnica wieńcowa (projekcja LAO 17\%, CRA $19^{\circ}$ ) - masywne wynaczynienie zakontrastowanej krwi po przedłużonej inflacji balonem postentowym; wyraźnie widoczne podwójne wrota perforacji na górnym biegunie oraz w środkowej części stentu

[7]. These include progression to heart failure, ischaemia caused by a damaged artery, and rare but extremely important clinical risk of infectious endocarditis. Therefore large fistulae caused by perforations unquestionably require treatment.

The anatomical conditions make the management in the present case particularly challenging. A therapeutic option may include surgical suturing or ligation of the artery with subsequent coronary artery bypass grafting [8]. However, it is easier to refer for surgery a patient with 3-vessel disease than a patient with 1-vessel disease (the patient had a history of a successful PCI of the CX with DES implantation) when the risk of cardiac surgery may outweigh the benefits. In that case a possibility of percutaneous intervention should be considered. Percutaneous methods include transcatheter introduction of coils, which is often used for the closure of congenital coronary fistulae [9]. Other methods of perforation closure such as thrombin or polyvinyl alcohol injection or embolisation using an autologous thrombus or geoflam cannot be applied due to a relatively large diameter of the fistula and rapid blood flow between the arterial and venous system and therefore should be reserved for type II and III perforations. 


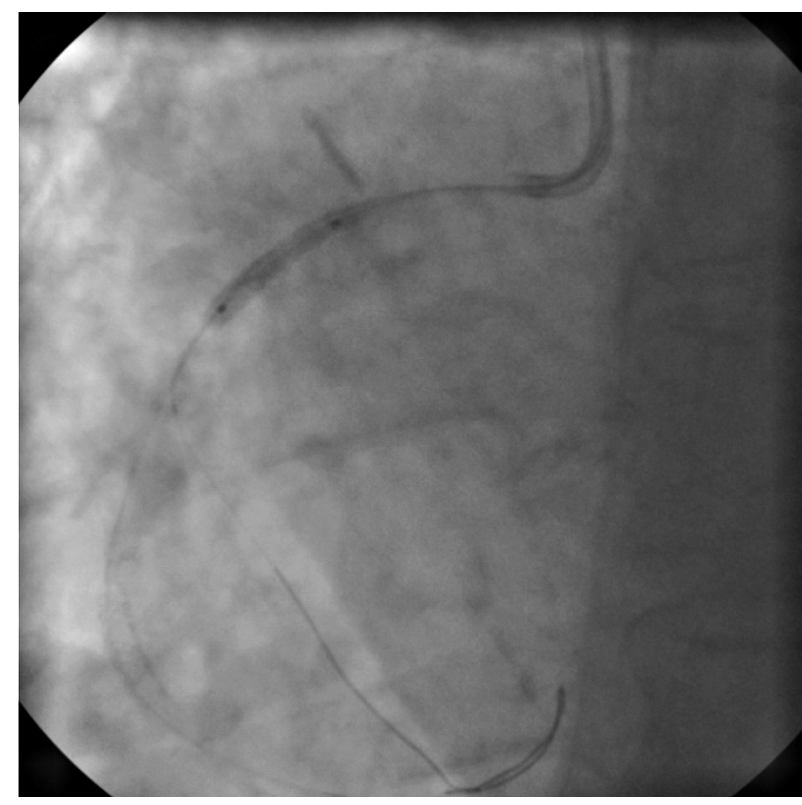

Fig. 8. Right coronary artery (LAO $2^{\circ}$, CRA $9^{\circ}$ view) - stent graft implantation at the site of the RCAright ventricular branch bifurcation; another guidewire placed in the right ventricular branch of the RCA is visible

Ryc. 8. Prawa tętnica wieńcowa (projekcja LAO 2, CRA $\left.9^{\circ}\right)$ - implantacja stentgraftu do RCA oraz początkowego odcinka gatęzi prawokomorowej; widoczny dodatkowy prowadnik w gatęzi prawokomorowej RCA

The traditional and commonly used method of perforation treatment consists of implantation of a polytetrafluoroethylene-covered stent graft [10]. The use of stent grafts may be considered for "cavity spilling" perforations only in cases where a guidewire is definitely placed in the true arterial lumen and the origin of the fistula is perpendicular to the arterial lumen. In that case, stent graft implantation leads to closure of the fistula ostium, which causes cessation of blood flow into the cardiac cavity. This was the situation described in that case. However, difficulties of stent graft introduction into the site of perforation excluded the use of that option. Successful solution of the problem consisted of stent graft implantation into the RCA-right ventricular branch bifurcation, which led to cessation of blood flow into the right ventricular cavity. At this point a much more challenging situation when closure of the branch may be a successful aid for the patient should be mentioned. In that case the intramural part of the fistula runs in the continuity of the vessel and therefore stent graft implantation would cause dilation of the perforation and increase of extravasation. Therefore partial localization of the stent graft inside the branch and closure of the vessel above the fistula would help to successfully take control of the situation. Despite a perfect

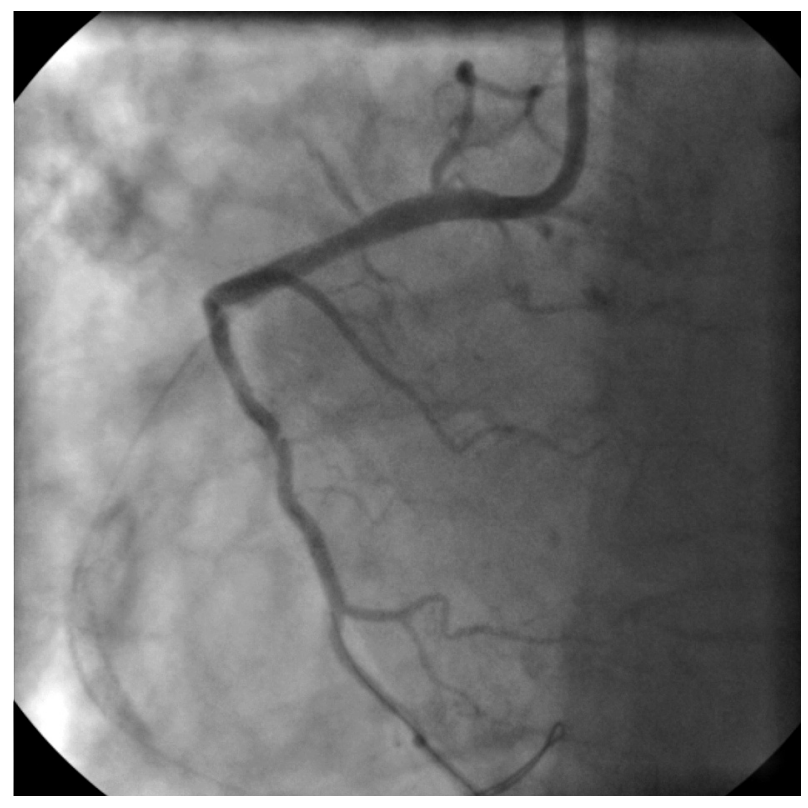

Fig. 9. Right coronary artery (LAO $2^{\circ}$, CRA $9^{\circ}$ view) - status after stent graft implantation, lack of contrast medium extravasation into the right ventricular cavity

Ryc. 9. Prawa tętnica wieńcowa (projekcja LAO $2^{\circ}$, CRA $9^{\circ}$ ) - po implantacji stentgraftu; brak wynaczynienia zakontrastowanej krwi do prawej komory

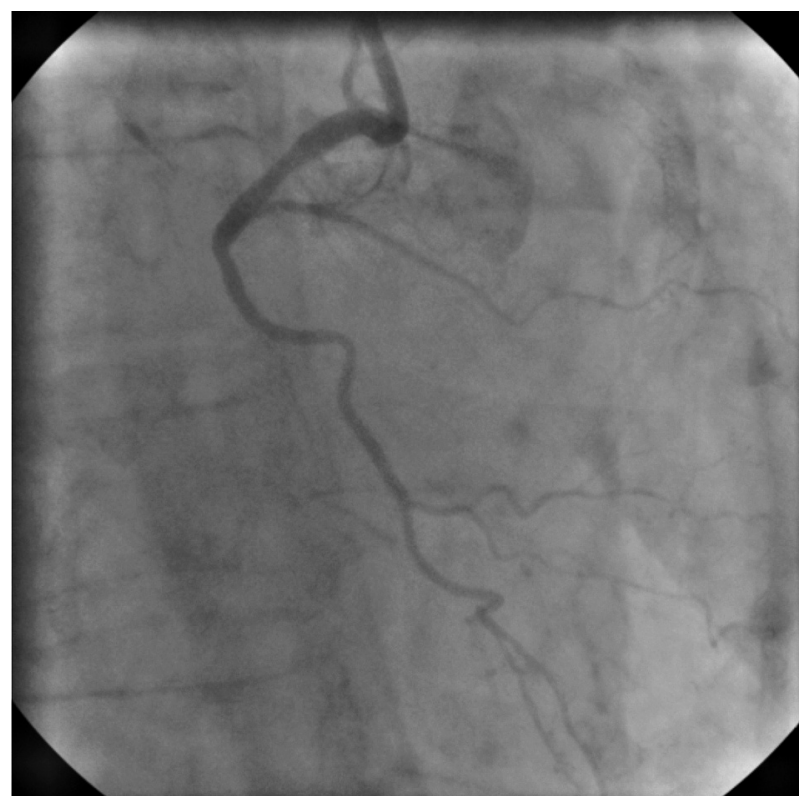

Fig. 10. Right coronary artery (RAO $26^{\circ}, \mathrm{CRA} 2^{\circ}$ view) - final result of the procedure

Ryc. 10. Prawa tętnica wieńcowa (projekcja RAO 26, CRA $2^{\circ}$ ) - ostateczny wynik zabiegu

angiographic effect of the stent graft implantation at the end of the procedure, one should remember that these stents are characterized by a higher risk of in-stent throm- 
bosis and require prolonged combined antiplatelet therapy. This type of stent is also characterized by a high restenosis rate and usually leads to occlusion of the side branches. For these reasons, the patient should remain under strict medical control to enable early detection of the described complications.

\section{References}

1. Ellis SG, Ajluni S, Arnold AZ, et al. Increased coronary perforation in the new device era. Incidence, classification, management, and outcome. Circulation 1994; 90: 2725-2730.

2. Gruberg L, Pinnow E, Flood R, et al. Incidence, management, and outcome of coronary artery perforation during percutaneous coronary intervention. Am J Cardiol 2000; 86: 680-682.

3. Gunning MG, Williams IL, Jewitt DE, et al. Coronary artery perforation during percutaneous intervention: incidence and outcome. Heart 2002; 88: 495-498.

4. Ramana RK, Arab D, Joyal D, et al. Coronary artery perforation during percutaneous coronary intervention: incidence and outcomes in the new interventional era. J Invasive Cardiol 2005. 17: 603-605.

5. Bittl JA, Ryan TJ Jr, Keaney JF Jr, et al.; The percutaneous Excimer Laser Coronary Registry. Coronary artery perforation during excimer laser coronary angioplasty. J Am Coll Cardiol 1993; 21: 1158-1165.

6. Wong CM, Kwong Mak GY, Chung DT. Distal coronary artery perforation resulting from the use of hydrophilic coated guidewire in tortuous vessels. Cathet Cardiovasc Diagn 1998; 44: 93-96.

7. Poormoghaddas $\mathrm{M}$, Fard $\mathrm{OH}$. Covered stents in iatrogenic coronary artery fistula; a case report. ARYA Atherosclerosis J 2009; 5: 142-5.

8. Celiento M, Scioti G, Pratali S, Bortolotti U. Repair of coronary artery perforation following angioblasty using TachoSil patches. Interact Cardiovasc Thorac Surg 2010; 10: 328-330.

9. Hendry C, Mahadevan V, Fath-Ordoubadi F. Successful percutaneous closure of coronary artery fistula with angiographic followup at 6 months. Catheter Cardiovasc Interv 2009; 73: 581-583.

10. Lansky AJ, Yang Y, Khan Y, et al. Treatment of coronary artery perforations complicating percutaneous coronary intervention with a polytetrafluoroethylene-covered stent graft. Am J Cardiol 2006; 98: 370-374. 